\title{
Gastric Trichobezoar in a Pediatric Patient
}

\author{
Tricobezoar Gástrico num Paciente Pediátrico
}

Marta Clara SOUSA ${ }^{1}$, Nuno ALVES ${ }^{1}$, Vasco HERÉDIA ${ }^{1}$

Acta Med Port 2014 Sep-Oct;27(5):665-665

Keywords: Child; Bezoars; Hair; Stomach.

Palavras-chave: Criança; Bezoares; Cabelo; Estômago.

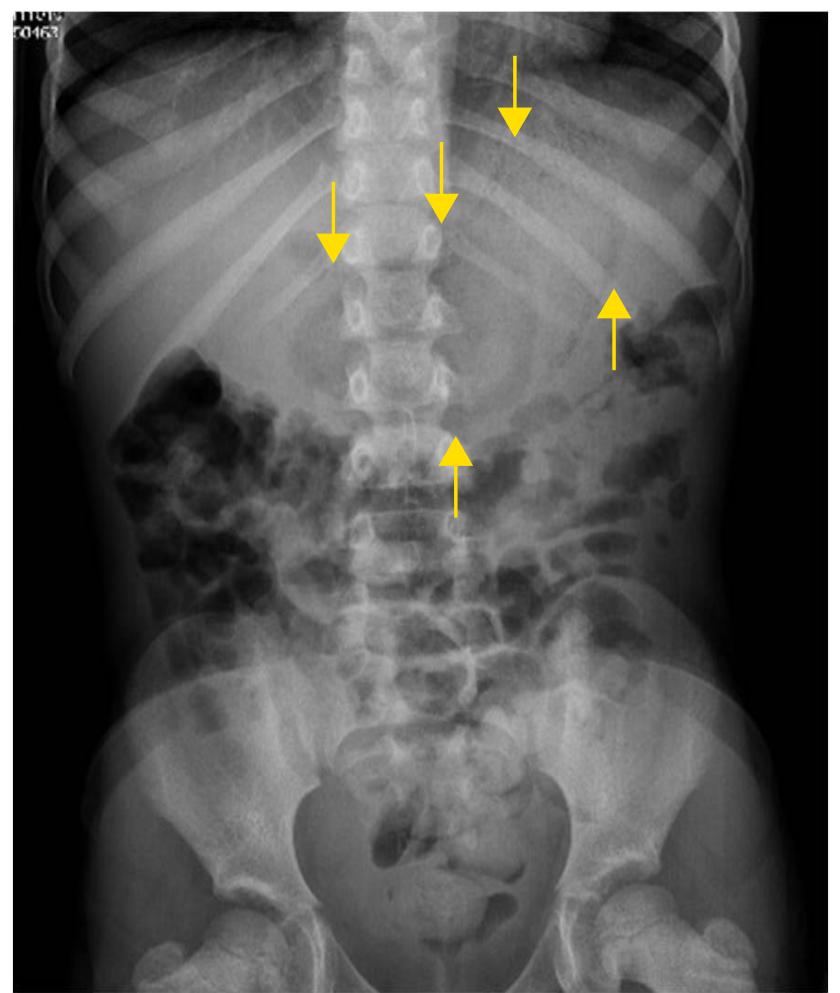

Figure 1 - The supine abdominal radiograph showed a heterogeneous mass within the stomach (arrows) containing small amounts of interspersed gas

A 7-year-old girl presented with a 2-day history of abdominal pain and postprandial vomiting. Examination revealed a large mobile epigastric mass but was otherwise unremarkable. On questioning, parents reported sporadic hair-pulling for the last 2 years raising suspicion of trichobezoar.

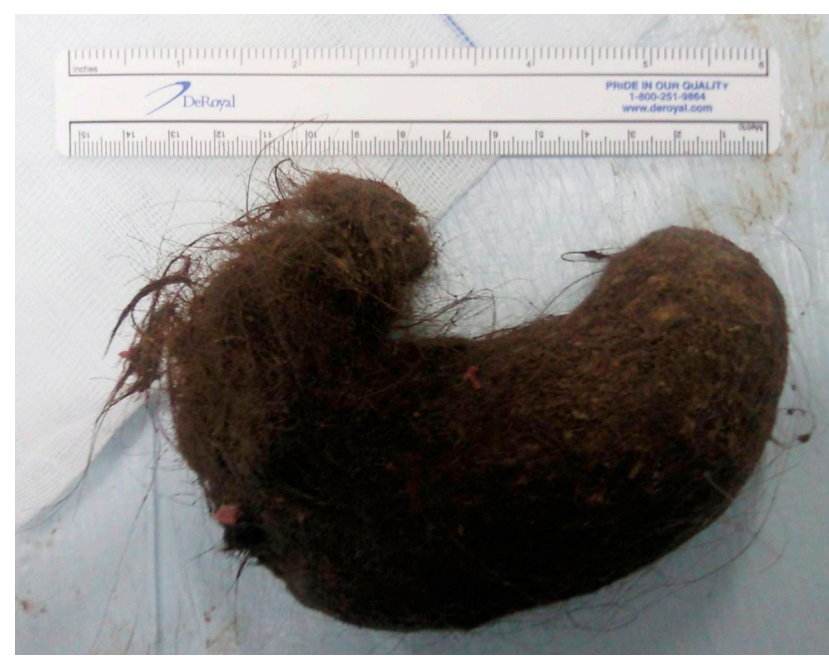

Figure 2 - A large stomach-shaped trichobezoar was extracted by gastrostomy

The abdominal radiograph confirmed a dilated stomach occupied by a curvilinear heterogeneous soft-tissue opacity outlined by a rim of air (Fig. 1, arrows) with resulting bowel displacement. Endoscopy was performed but due to the size of the trichobezoar, removal was undertaken successfully by gastrostomy (Fig. 2). The patient had an uneventful recovery and was discharged for pedopsychiatry.

This condition is classically seen in female children or adolescents often with an underlying socio-psychiatric problem. They share an irrational urge to pull (trichotillomania) and swallow hair (trichophagia). ${ }^{1,2}$

Gastrointestinal trichobezoars can cause a spectrum of findings but this singular cause of obstruction should not be forgotten in the management of a child with abdominal pain.

\section{REFERENCES}

1. Megale AB, Megale MZ, Miranda TA, Barbosa BO, Lourenço AL. Gastric trichobezoar - case report. Rev Col Bras Cir. 2010;37:382-83.

2. Kinoo SM, Singh B. Gastric trichobezoar: an enduring intrigue. Case Rep Gastrointest Med. 2012;2012:136963. 
Marta Clara SOUSA, Nuno ALVES, Vasco HERÉDIA

\section{Gastric Trichobezoar in a Pediatric Patient}

Acta Med Port 2014:27:665-665

Publicado pela Acta Médica Portuguesa, a Revista Científica da Ordem dos Médicos

Av. Almirante Gago Coutinho, 151

1749-084 Lisboa, Portugal.

Tel: +351218428 215

E-mail: submissao@actamedicaportuguesa.com

www.actamedicaportuguesa.com

ISSN:0870-399X | e-ISSN: 1646-0758

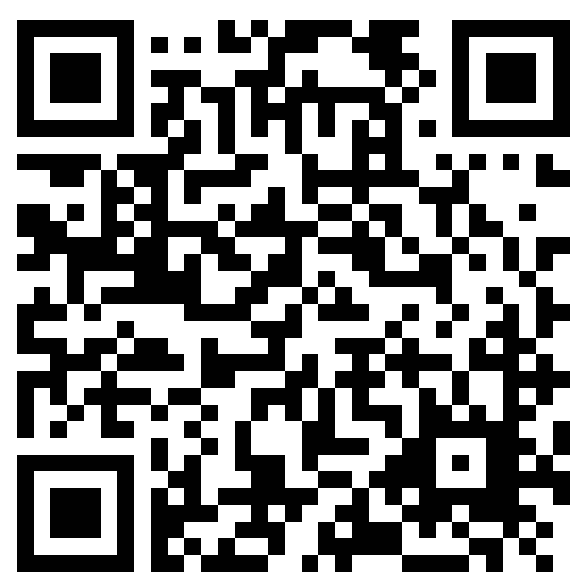

